\title{
Stability of Corynosoma populations with fluctuating population densities of the seal definitive host
}

\author{
E. T. VALTONEN ${ }^{1 *}$, E. HELLE ${ }^{2}$ and R. POULIN ${ }^{3}$ \\ ${ }^{1}$ Department of Biological and Environmental Science, University of Fyväskylä, P.O. Box 35, FIN-40014 University of \\ Fyväskylä, Finland \\ ${ }^{2}$ Finnish Game and Fisheries Research Institute, P.O. Box 6, FIN-00721 Helsinki, Finland \\ ${ }^{3}$ Department of Zoology, University of Otago, P.O. Box 56, Dunedin, New Zealand
}

(Received 11 February 2004; revised 4 March and 7 March 2004; accepted 18 March 2004)

\section{S U M M A R Y}

In theory there should be a strong coupling between host and parasite population sizes. Here, we investigated population size and structure in 3 species of acanthocephalans, Corynosoma semerme, C. strumosum and C. magdaleni, in ringed seals (Phoca hispida) from the Bothnian Bay over a period of more than 20 years. During this period, seal numbers first decreased markedly and then increased steadily; at the same time, a paratenic fish host particularly important for C. strumosum has gradually disappeared from the bay due to decreasing salinity. We found no evidence that the mean abundance of any of the 3 acanthocephalan species changed significantly over time, nor was there any relationship between parasite abundance at any point in time and seal numbers in the corresponding year. Based on the proportion of sexually mature female worms per infrapopulation, and on relationships between the sex ratio of worms and infrapopulation size, both C. magdaleni and $C$. semerme appear to be doing well, independently of the population size of their seal definitive hosts. In contrast, perhaps because of the loss of its main paratenic host, C. strumosum appears more at risk in the Bothnian Bay. Our results show that in complex natural systems, there are not necessarily simple, direct links between definitive host population size or density, and parasite population dynamics.

Key words: stability, acanthocephalan population, host population, Corynosoma, seals.

\section{INTRODUCTION}

Epidemiological models predict that the population dynamics of parasites is tightly linked with that of their hosts (see Anderson \& May, 1978, 1979; May \& Anderson, 1978, 1979; and all subsequent extensions of these basic models). The reason for this is the strong dependence of parasite transmission success on host population density. The transmission rate of most parasites increases with host density; as host population density declines, it theoretically reaches a threshold point below which transmission rates are too low to allow the parasite population to persist. Despite the biological logic of these basic assumptions, there is practically no evidence, from natural populations monitored over long periods of time, that changes in the abundance or density of hosts may generate fluctuations in the populations of their parasites. At the same time, parasite population size will depend on abiotic conditions, since the survival of free-living stages of the parasite or of its intermediate hosts will depend on environmental variables. Here, we investigate long-term changes in the abundance and structure of acanthocephalan

* Corresponding author: Department of Biological and Environmental Science, P.O. Box 35, FIN-40014 University of Jyväskylä, Finland. Tel: + 35850 5662201. Fax: +358142602321.E-mail: etvalto@bytl.jyu.fi populations in their definitive hosts, in a system where changes have occurred in the population sizes of paratenic and definitive hosts, and in a key environmental factor.

The Baltic Sea is the largest brackish water area in the world, where salinity decreases from $1.5 \%$ in the proper Baltic to $0.7 \%$ in SW Finnish Archipelago, and further north in the Gulf of Bothnia, in the northern Bothnian Bay, it drops to $0 \cdot 3 \%$. Atlantic ringed seals (Phoca hispida) invaded the Baltic basins during the deglaciation ca. 11500 years ago (Donner, 1995). Population size of the Baltic ringed seal used to be large, ca. 100 000-300 000 (Hårding \& Härkönen, 1999; Kokko et al. 1999) but has declined in the 19 th and 20th century due to human activities. Due to heavy harvesting and reproductive disorders, most probably caused by environmental toxins, the ringed seal numbers collapsed during the 1900's until the early 1980's (e.g. Helle, 1980), but have begun to increase since then. In the mid 1990's an estimated haul-out population of 5500 ringed seals inhabited three separate breeding areas in the Baltic Sea, the largest stock being found in our study area in the Bothnian Bay (ca. 4000 hauling-out individuals) (Härkönen et al. 1998). Another seal species, the grey seal (Halichoerus grypus), also lives in the Bothnian Bay. The present distribution of the grey seal covers almost the whole of the Baltic Sea, although the species has a more southerly main 
distribution area in the central Baltic Sea. However, in our study area grey seals were mainly seasonal visitors until the mid-1980's. Since then the grey seal numbers have been slowly increasing at the same time as the whole of the Baltic population (Helle, unpublished observations), but the numbers still remain low in the Bothnian Bay compared to the ringed seal population. In other seas of the world grey and ringed seals do not occur sympatrically to any large extent as they do in the Baltic Sea. Currently, Baltic ringed seals are protected, except for a few individuals taken for scientific purposes, and small numbers of grey seals are taken annually mostly in connection with damages caused to fisheries.

Significant efforts have been directed toward understanding Baltic seal ecology, including their intestinal parasites (Helle \& Valtonen, 1980, 1981; Valtonen \& Helle, 1988). Here we use data on intestinal acanthocephalans of ringed seals collected from the NE Bothnian Bay from 1977 to 1999. The data are somewhat patchy because these seals, like many other marine mammals, have been protected and could not have been sampled solely to meet the needs of a parasitological investigation. However, as long-term studies of naturally occurring infections and host population sizes are rare, our data serve well-despite some shortcomings - to demonstrate the population stability of acanthocephalan species over time.

Component communities of intestinal metazoan parasites of ringed seals in the northern Gulf of Bothnia (Bothnian Bay) are among the most depauperate known in any marine mammal. Only Corynosoma semerme and C. strumosum were recorded in great numbers (Helle \& Valtonen, 1980, 1981; Valtonen \& Helle, 1988) in addition to the rarer Schistocephalus solidus (see Chubb et al. 1995) and unidentifiable Diphyllobothrium larvae (Valtonen \& Helle, unpublished data). The finding of C. magdaleni in a few ringed seals from the Gulf of Finland by Delyamure, Popov \& Trashchenkov (1980) induced Nickol, Helle \& Valtonen (2002) to study the role of the grey seal-type host species of $C$. magdaleni as a source of $C$. magdaleni infection in the Baltic. The same authors noted that an accurate discrimination of C. magdaleni from C. strumosum is necessary. They also suggested it is likely that $C$. magdalen $i$ had been unrecognized in earlier reports of parasites from seals due to the poor description of the species and the conditions under which seals are collected, making it difficult to process acanthocephalan specimens in the conventional manner. The finding of C. magdaleni from the ringed seals in the Gulf of Finland by Delyamure et al. (1980) prompted Nickol et al. (2002) to consider that the Baltic ringed seal may have become a definitive host of $C$. magdaleni when living sympatrically with the Baltic grey seal. Nickol et al. (2002) showed that both $C$. magdaleni and $C$. stumosum mature equally well in grey and ringed seals in the Finnish SW Archipelago Sea. The third Corynosoma species, C. semerme, also matures equally well in both seal species. In the Bothnian Bay, however, only the permanent ringed seal population serves as important definitive hosts for the acanthocephalans.

In addition to the changes in the population size of ringed seals mentioned above, populations of another host of Corynosoma have also been changing over time. The bull-rout (Myoxocephalus scorpius), a marine sculpin that was the most heavily infected paratenic host for C. strumosum at the end of the 1970's (see Valtonen, $1983 a, b$ ), has gradually disappeared from the Bothnian Bay (Catch statistics of the Bothnian Bay Research Station and Timola, unpublished observations) as the salinity has decreased in the bay (Wikner, 1996). The consequences for the transmission dynamics of this parasite have not been explored to date, but this system also allows the indirect impact of environmental changes on parasites to be investigated.

Our specific objectives were to (1) quantify the population structure, i.e. the sex ratio and proportion of females that are reproductively mature, of the 3 Corynosoma species, and determine whether it relates to intensity of infection; (2) document changes in the population size of ringed seal definitive hosts and the population densities of the intermediate host, the benthic amphipod Monoporeia affinis, from the 1970s to the late 1980s; and (3) assess whether mean abundance of the 3 parasite species changed over the time-period 1977 to 1999 and determine how this related to the population size of the definitive host. Overall, these results from a long-term field study will provide an indication of how changes in host abundance and a key environmental variable (i.e. salinity) may have impacted parasite populations.

\section{MATERIALS AND METHODS}

Acanthocephalans were collected from the alimentary tracts of 109 adult ringed seals between 1977-1999 from the Bothnian Bay (salinity 0.3-0.5\%). The majority of the seals were 10-20 years old. Forty-one of the seals were caught with seal nets off the coast of Simo $\left(65^{\circ} 35^{\prime} \mathrm{N}, 25^{\circ} 00^{\prime} \mathrm{E}\right)$ in the autumn of 1977 , 1979 and 1981, and 68 seals were shot in the Central Bothnian Bay in spring or early summer between 1978 and 1999 (see Fig. 1 in Valtonen \& Helle, 1988). The alimentary tracts were kept deep-frozen in most cases until examination for acanthocephalans. Until 1982 we identified specimens as either C. strumosum (Rudolphi, 1802) Lühe, 1904, or C. semerme (Forssell, 1904) Lühe, 1905 according to Petrochenko (1956). From 1988 onwards C. magdaleni were separated from C. strumosum following the descriptions later proposed by Nickol et al. (2002). The worms were preserved in $70 \%$ ethanol and cleared in lactophenol or they were studied from 
Table 1. Ringed seals collected in spring (s) and autumn (a) between 1977-1999 from the Bothnian Bay, Baltic Sea

(Prevalences (\%) and mean abundances ( $x$ and s.D.) are given for C. semerme, C. strumosum and C. magdaleni in 1988-1999. During 1977-1982 the same values are given for C. semerme and joint infections of $C$. magdaleni and $C$. strumosum called 'C. strumosum' in the table.)

\begin{tabular}{|c|c|c|c|c|c|c|c|c|}
\hline \multirow[b]{3}{*}{ Year } & \multirow[b]{3}{*}{ No. seals } & \multicolumn{3}{|l|}{ C. semerme } & \multicolumn{3}{|c|}{ 'C. strumosum' } & \multirow{3}{*}{$\begin{array}{l}\text { Ratio } \\
\text { sem: 'strum' }\end{array}$} \\
\hline & & \multirow{2}{*}{$\begin{array}{l}\text { Prevalence } \\
\%\end{array}$} & \multicolumn{2}{|l|}{ Abundance } & \multirow{2}{*}{$\begin{array}{l}\text { Prevalence } \\
\%\end{array}$} & \multicolumn{2}{|l|}{ Abundance } & \\
\hline & & & $x$ & S.D. & & $x$ & S.D. & \\
\hline 1977a & 29 & $96 \cdot 6$ & $135 \cdot 7$ & $233 \cdot 2$ & $96 \cdot 6$ & $67 \cdot 0$ & $82 \cdot 5$ & $2 \cdot 0$ \\
\hline $1978 \mathrm{~s}$ & 13 & 100 & 510 & $461 \cdot 3$ & 100 & $80 \cdot 2$ & $78 \cdot 9$ & $6 \cdot 4$ \\
\hline $1979 \mathrm{~s}$ & 9 & 100 & $441 \cdot 6$ & $883 \cdot 2$ & 100 & $46 \cdot 4$ & $61 \cdot 8$ & $9 \cdot 5$ \\
\hline $1979 a$ & 10 & 100 & $31 \cdot 3$ & $26 \cdot 4$ & 100 & $46 \cdot 5$ & $29 \cdot 8$ & $0 \cdot 7$ \\
\hline $1980 \mathrm{~s}$ & 10 & 100 & $233 \cdot 6$ & $272 \cdot 2$ & 100 & $29 \cdot 4$ & 22 & $7 \cdot 9$ \\
\hline 1981s & 6 & 100 & $882 \cdot 7$ & $828 \cdot 1$ & 100 & $34 \cdot 2$ & $13 \cdot 3$ & $25 \cdot 8$ \\
\hline $1981 \mathrm{a}$ & 2 & 100 & 132 & $137 \cdot 2$ & 100 & $14 \cdot 5$ & $3 \cdot 5$ & $9 \cdot 1$ \\
\hline \multirow[t]{2}{*}{$1982 \mathrm{~s}$} & 5 & 100 & $389 \cdot 8$ & $606 \cdot 7$ & 100 & $40 \cdot 6$ & $26 \cdot 8$ & $9 \cdot 6$ \\
\hline & 84 & $98 \cdot 8$ & $275 \cdot 4$ & $472 \cdot 9$ & $98 \cdot 8$ & $54 \cdot 7$ & $64 \cdot 5$ & $5 \cdot 4$ \\
\hline $1988 s$ & 10 & 100 & $78 \cdot 9$ & $68 \cdot 3$ & 100 & 88 & $141 \cdot 9$ & $0 \cdot 9$ \\
\hline $1993 \mathrm{~s}$ & 5 & 100 & 195 & $138 \cdot 3$ & 100 & $18 \cdot 2$ & $22 \cdot 3$ & $10 \cdot 7$ \\
\hline $1996 \mathrm{~s}$ & 3 & 100 & $605 \cdot 7$ & $615 \cdot 5$ & 100 & $36 \cdot 3$ & $14 \cdot 6$ & $16 \cdot 7$ \\
\hline \multirow[t]{4}{*}{$1999 \mathrm{~s}$} & 7 & 100 & $117 \cdot 3$ & $96 \cdot 7$ & 100 & $33 \cdot 9$ & $63 \cdot 3$ & $3 \cdot 5$ \\
\hline & 25 & 100 & $176 \cdot 1$ & $258 \cdot 7$ & 100 & $52 \cdot 7$ & $97 \cdot 8$ & $3 \cdot 3$ \\
\hline & & \multicolumn{3}{|c|}{ C. magdaleni } & \multicolumn{3}{|c|}{ C. strumosum } & \multirow{2}{*}{$\begin{array}{l}\text { Ratio } \\
\text { magd : strum }\end{array}$} \\
\hline & & Prevalence & Abundance & S.D. & Prevalence & Abundance & S.D. & \\
\hline $1988 s$ & 10 & 90 & $65 \cdot 2$ & $142 \cdot 2$ & 80 & $22 \cdot 8$ & $24 \cdot 3$ & $2 \cdot 9$ \\
\hline $1993 \mathrm{~s}$ & 5 & 80 & $10 \cdot 2$ & $18 \cdot 8$ & 80 & 8 & $9 \cdot 9$ & $1 \cdot 3$ \\
\hline $1996 \mathrm{~s}$ & 3 & 100 & 25 & $16 \cdot 7$ & 100 & $11 \cdot 3$ & $4 \cdot 5$ & $2 \cdot 2$ \\
\hline \multirow[t]{2}{*}{$1999 \mathrm{~s}$} & 7 & $85 \cdot 7$ & $18 \cdot 6$ & $36 \cdot 2$ & $71 \cdot 4$ & $15 \cdot 3$ & $27 \cdot 5$ & $1 \cdot 2$ \\
\hline & 25 & 84 & $36 \cdot 3$ & $92 \cdot 3$ & 80 & $16 \cdot 4$ & $21 \cdot 6$ & $2 \cdot 2$ \\
\hline
\end{tabular}

fresh slides illuminated from beneath. The sex of each individual worm and the developmental stage of each female worm were recorded. The females were judged to be mature if eggs (shelled acanthors) were found in their body cavities.

The relative abundance of the ringed seal has been monitored using the size of the haul-out population since 1975 , first by Helle $(1980,1986)$ and later by Härkönen et al. (1998, and T. Härkönen, unpublished observations), by aerial transect or strip censuses. Censuses have been carried out in mid-April-early May during the moult, when ringed seals are hauling out of water on the ice. This is the time of the year when seals are countable in their highest frequencies. As most of the population can be reached in the surveys, aerial censuses are considered repeatable and reliable in reflecting population size in relative terms.

Densities of Monoporeia affinis (Syn. Pontoporeia affinis), the only abundant amphipod in the Bothnian Bay (Leonardsson et al. 1996) and the sole intermediate host of all Corynosoma species, were obtained from the established annual benthic sampling programme in the Central Bothnian Bay, performed by the Finnish Institute of Marine Research.
Variables that required transformation to meet the assumptions of parametric tests were logtransformed; these consisted of data on intensity of infection by each of the parasite species, and host population sizes or densities.

\section{RESULTS}

Throughout the 2 main study periods (1977-1982 and 1988-1999) extending over 22 years, all ringed seals except one (108/109) were infected with Corynosoma semerme. Mean abundances in yearly samples varied from 31 to 882 . Mean $C$. semerme abundance in 84 seals during $1977-1982$ was $275 \cdot 4$ (s.D. $472 \cdot 9$ ) and did not differ significantly from that in 25 seals in 1988-99 (mean $176 \cdot 1$ s.D. 258.7) (Table 1) (one way ANOVA on log-transformed data $\mathrm{F}=0.009, P=$ 0.9239). Similarly, all seals except one were infected with 'C. strumosum' type species. Its average abundances were nearly equal between the 2 periods, however, mean abundances being 54.7 (S.D. 64.5) in 1977-1982, and 52.7 (s.D. 97.7) in 1988-1999.

In the latter period (1988-1999) when C.strumosum and $C$. magdaleni were distinguished as separate 
Table 2. Proportion of males out of all worms, and mature females among all females in ringed seal samples collected in 1988-1999 from the Bothnian Bay, Baltic Sea

\begin{tabular}{lrll}
\hline \hline $\begin{array}{l}\text { C. semerme } \\
\text { Year }\end{array}$ & $\begin{array}{l}\text { Total } \\
\text { no. }\end{array}$ & $\begin{array}{l}\text { Males } \\
\%\end{array}$ & $\begin{array}{l}\text { Mature } \\
\text { females \% }\end{array}$ \\
\hline 1988 & 789 & $25 \cdot 1$ & $37 \cdot 7$ \\
1993 & 975 & $21 \cdot 7$ & $59 \cdot 7$ \\
1996 & 1817 & $32 \cdot 9$ & 46 \\
1999 & 821 & 31 & $40 \cdot 3$ \\
\cline { 2 - 4 } & 4402 & $26 \cdot 9$ & $46 \cdot 6$ \\
C. strumosum & & & $39 \cdot 5$ \\
1988 & 228 & $31 \cdot 1$ & 50 \\
1993 & 40 & 15 & 0 \\
1996 & 34 & $35 \cdot 3$ & $27 \cdot 5$ \\
1999 & 107 & $35 \cdot 5$ & $34 \cdot 8$ \\
& 409 & $31 \cdot 1$ & \\
C.magdaleni & & & $95 \cdot 7$ \\
1988 & 652 & $21 \cdot 7$ & $62 \cdot 5$ \\
1993 & 51 & $37 \cdot 3$ & $35 \cdot 9$ \\
1996 & 75 & 48 & $44 \cdot 9$ \\
1999 & 130 & $46 \cdot 9$ & 85 \\
\hline \hline
\end{tabular}

species (see Nickol et al. 2002), C. magdaleni had a slightly higher prevalence on average than $C$. strumosum, and its mean abundance in the 25 seals was twice as high as that of C. strumosum.

When examining the ratio of $C$ semerme to 'C. strumosum' specimens in yearly samples, we can see that in all samples except 2 (autumn 1979 and spring 1988), C. semerme was numerically dominant. The ratio of the 2 'C. strumosum' types in 1988-1999 was always in favour of $C$. magdaleni, the largest annual dominance for C. magdaleni being 2.9 (Table 1).

In the years 1988-1999, the proportion of worms of each of the 3 Corynosoma species that were males were roughly the same for the 3 species, around $25-30 \%$ (Table 2). However, the proportion of females that were sexually mature was high in $C$. magdaleni and rather low in C. strumosum, with $C$. semerme having intermediate values (Table 2). The proportion of mature females was not related to the intensity of infection for $C$. semerme (including all seals, $P=0 \cdot 144)$, but the 2 variables were positively correlated for both $C$. magdaleni and $C$. strumosum $(r=0 \cdot 66, P=0 \cdot 002$, and $r=0 \cdot 72, P=0 \cdot 001$, respectively, including only seals from 1988-1999). Thus, for the latter 2 species, the more worms per host, the higher the proportion of mature females, although these relationships are in part due to the fact that there are generally no mature females at all in smaller infrapopulations (Fig. 1). Still, this indicates a disproportionate increase in reproductive potential with increasing infrapopulation size.

Across all seals sampled there was a positive relationship between intensity of infection and the
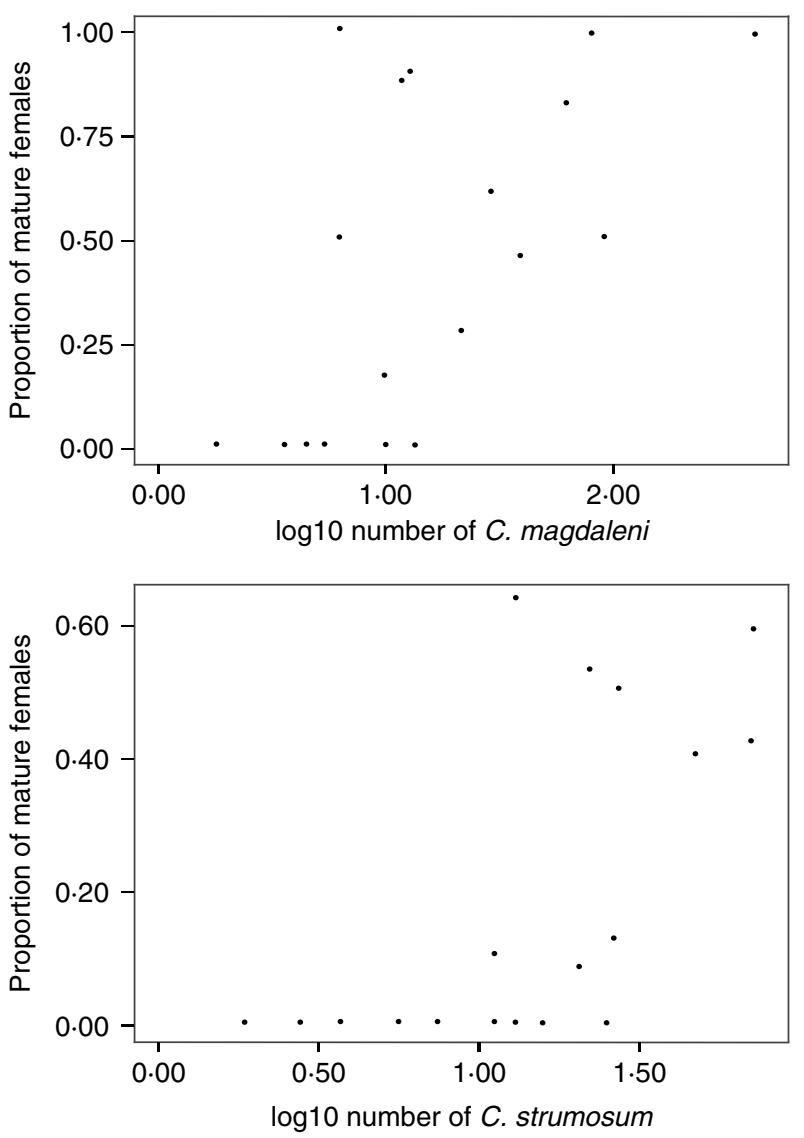

Fig. 1. Proportion of female worms that are sexually mature as a function of intensity of infection for both Corynosoma magdaleni (top) and C. strumosum (bottom) in ringed seals from the Bothnian Bay.

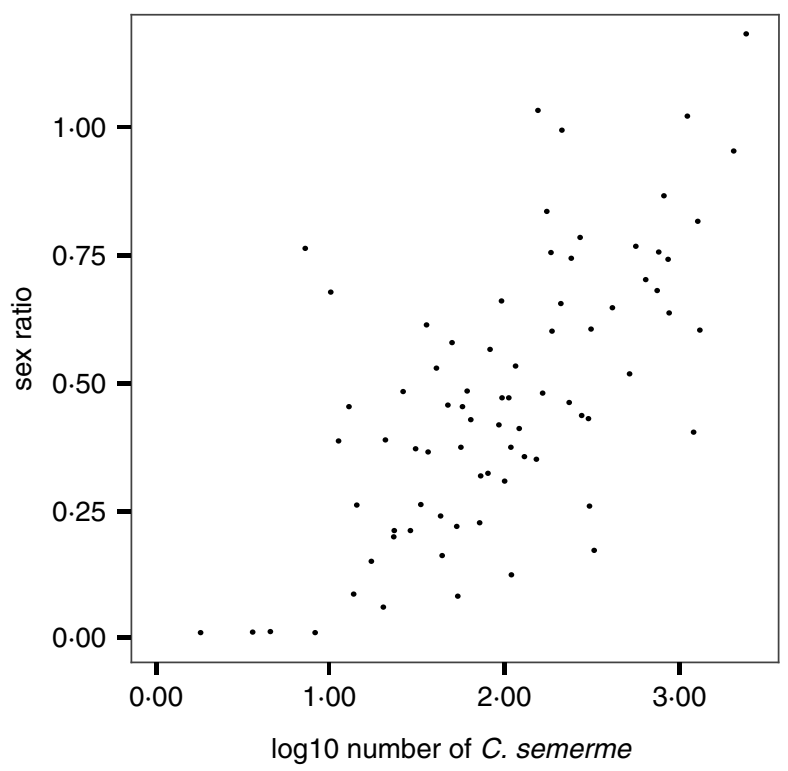

Fig. 2. Male-to-female sex ratio as a function of intensity of infection for Corynosoma semerme in ringed seals from the Bothnian Bay.

male-to-female sex ratio for $C$. semerme $(r=0.632$, $P<0.001)$ (Fig. 2). No such relationship was observed for C. magdaleni and C. strumosum, whether the 2 species were considered separately among 


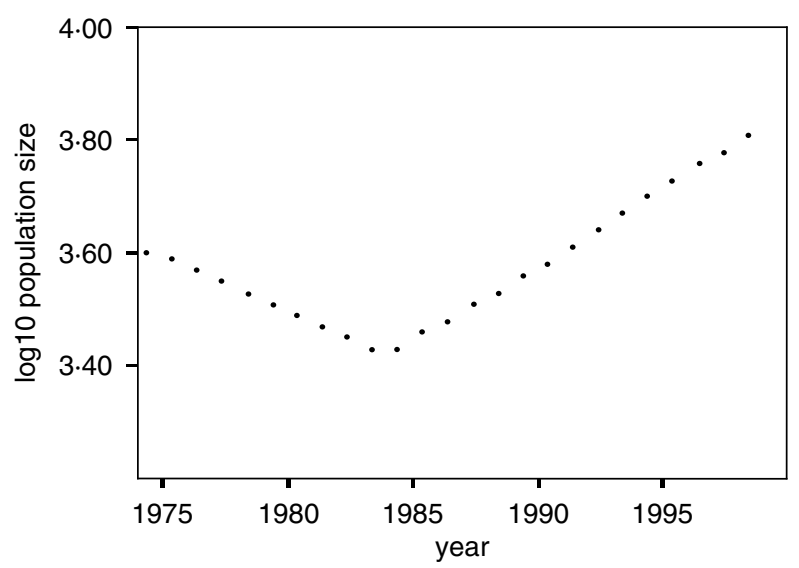

Fig. 3. Population size of ringed seals in the Bothnian Bay from 1975 to 1999.

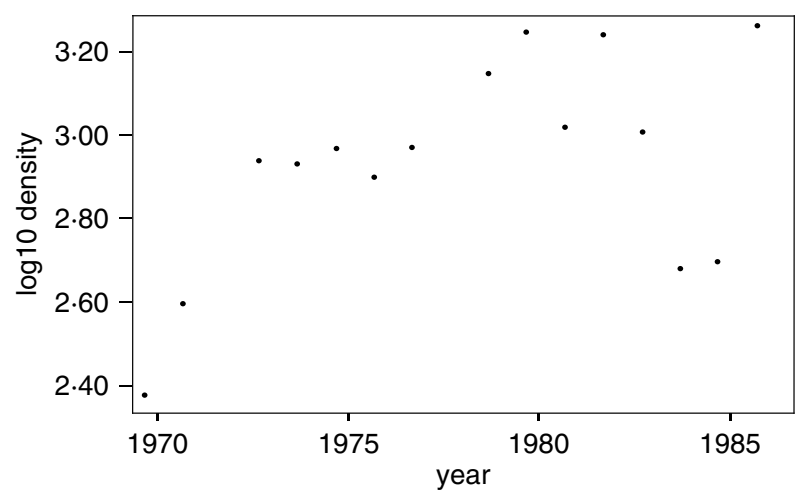

Fig. 4. Population densities of the benthic amphipod Monoporeia affinis in the Bothnian bay from 1970 to 1986.

seals from 1988 to 1999 only ( $P=0 \cdot 118$ and $0 \cdot 962$, respectively), or together across all seals sampled $(P=0 \cdot 654)$.

The population of ringed seals in the Bothnian Bay decreased gradually until the mid-1980s and has been increasing steadily since (Fig. 3). During that period, the population densities of the amphipod Monoporeia affinis, the intermediate host of all 3 Corynosoma species, have not increased significantly $(r=0 \cdot 486, P=0 \cdot 066$; see Fig. 4$)$. There have been no corresponding changes in mean abundance of the parasites. The mean abundance of $C$. semerme and 'C. strumosum' (i.e., combined numbers of $C$. strumosum and C. magdaleni) has shown no significant monotonic change over the period 1977-1999 (both $P \geqslant 0 \cdot 147)$ : despite some fluctuations, there has been no general increase or decrease in the abundance of these parasites (Fig. 5). Furthermore, there was no general decrease prior to 1985 , or general increase following 1985, in the abundance of the Corynosoma species, to mirror the corresponding decrease and increase in seal population size (all $P>0 \cdot 13$ ). The abundance of $C$. semerme post-1985 does appear to increase (Fig. 5), but with only 4 points it is not possible to conclude that this is a significant trend.

In addition, there is no correlation between the mean annual abundance of either $C$. semerme or
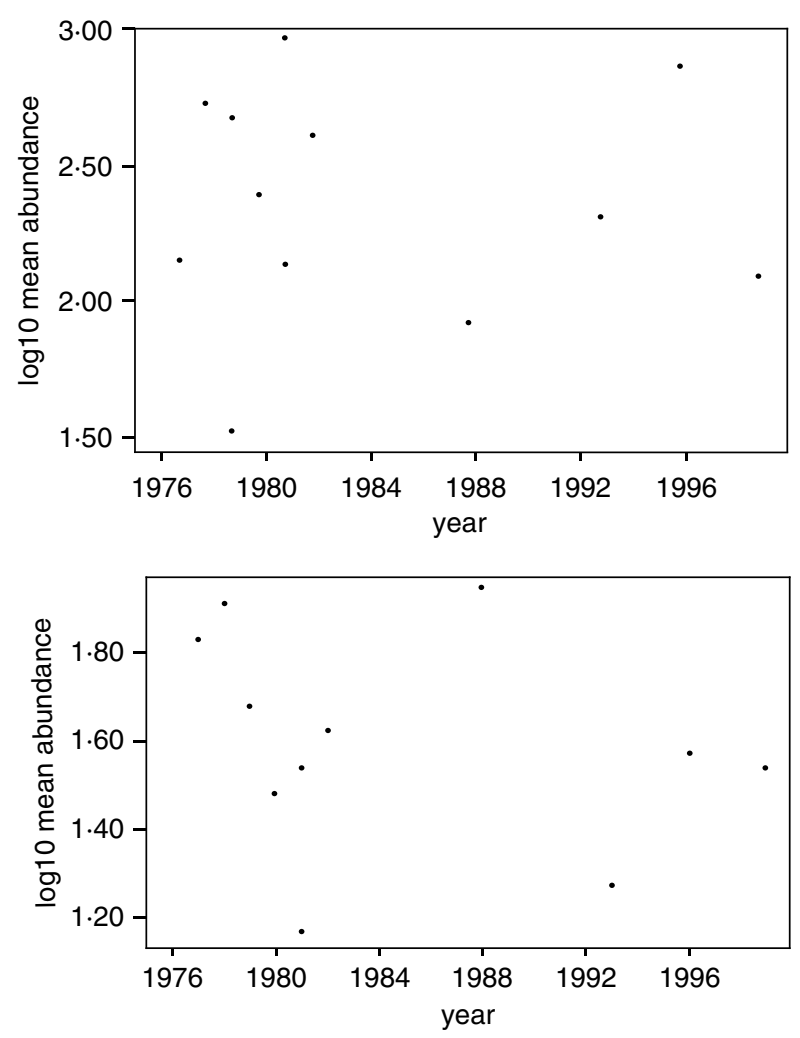

Fig. 5. Mean annual abundance of the acanthocephalans Corynosoma semerme (top) and 'C. strumosum', i.e. combined numbers of C. strumosum and C. magdaleni, (bottom) in ringed seals from the Bothnian Bay from 1977 to 1999 . In the latter figure two points overlap.

'C. strumosum' and the corresponding annual size of the seal population (both $P \geqslant 0 \cdot 845$ ). Thus, whether seals are abundant or not has no obvious effect on parasite abundance per host (Fig. 6). Because of the complex life-cycle of the acanthocephalans and their use of paratenic hosts, there may be a time delay between any changes in host population size and corresponding changes in acanthocephalan abundance. If we include 1-, 2- or 3-year time lags in the preceding correlations, to see whether parasite abundance changes 1, 2 or 3 years following a change in seal population size, we still obtain no significant relationships $(P>0 \cdot 65)$. A similar analysis could not be done using densities of the amphipod intermediate host, as these were not regularly collected in years of seal sampling.

\section{DISCUSSION}

Despite the strong link between host population size and parasite population dynamics predicted by epidemiological theory (see Anderson \& May, 1978, 1979; May \& Anderson, 1978, 1979), examples of this link in natural systems are rare. Here, we have investigated changes in acanthocephalan abundance in a system where the population size of the definitive host has decreased and then increased over a period 

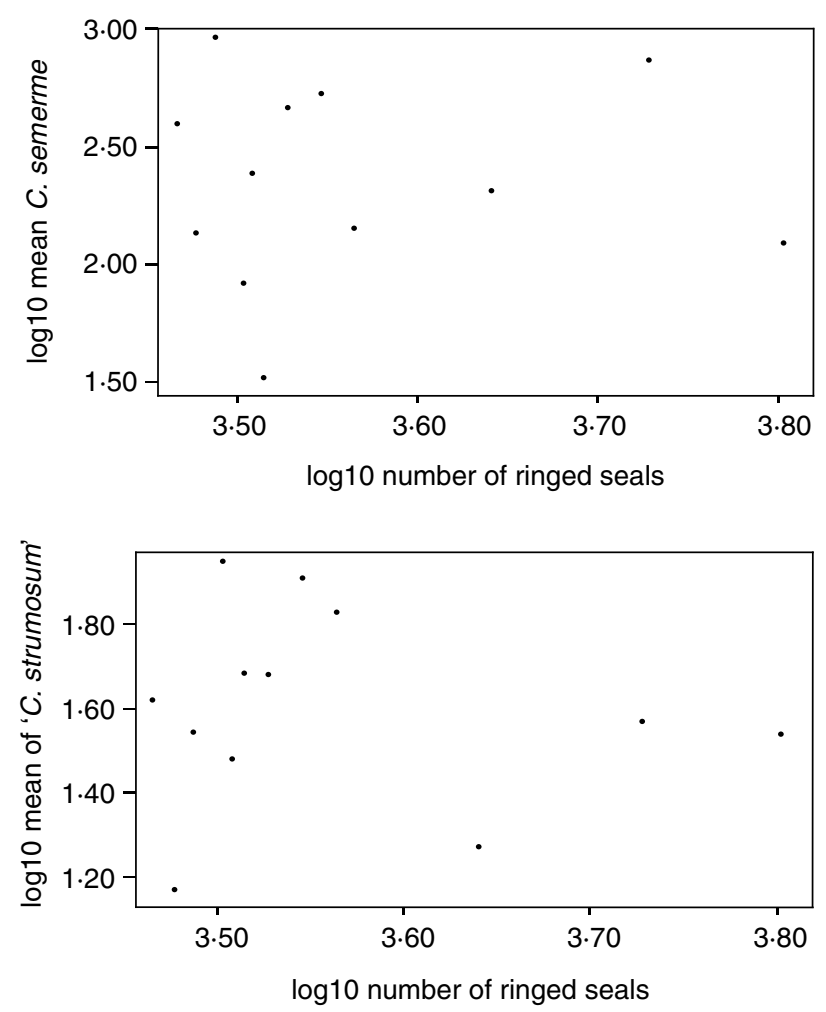

Fig. 6. Mean annual abundance of the acanthocephalans Corynosoma semerme (top) and 'C. strumosum', i.e. combined numbers of C. strumosum and C. magdaleni, (bottom) in ringed seals from the Bothnian Bay, as a function of seal population size in the corresponding year.

of $>20$ years. Of course, our data only cover the tail end of what has been a severe reduction in the numbers of ringed seals, from $>100000$ to just a few thousands; still, the seal population size varied 2 -fold during our study period, and at its smallest size it may have approached some threshold for acanthocephalan transmission. During that time, the population densities of the sole intermediate host have somewhat increased, while a paratenic host important for at least one of the acanthocephalans has gradually disappeared from the study area (Catch statistics of the Bothnian Bay Research Station). Our data present only a series of snapshots of this dynamic system, but given the magnitude of some of the changes in the population sizes or densities of the host species, one might expect measurable changes in the population abundance of the parasites.

What seems to have happened to the parasites is not as obvious as one might have expected. Populations of Corynosoma magdaleni seem to be doing well. Although they are generally not too abundant in seals, these worms include a high percentage of sexually mature females and this percentage increases with intensity of infection. More importantly, mean abundance of $C$. magdaleni has not changed over the years in any way suggesting that this species was not threatened at any time. To some extent, the same is true of $C$. semerme. This species is the most abundant of the 3 acanthocephalans and, although the proportion of mature females in this species does not vary with infection intensity, large infrapopulations tend to include a greater proportion of males. This guarantees that the overall reproductive output is always high because each female has a high probability of being mated.

The mean annual abundance also did not vary over time whatever happened to the population size of seals. Both $C$. magdaleni and $C$. semerme are known from land-locked lake populations of seals. C. magdaleni only was found in Lake Saimaa (Sinisalo, Kunnasranta \& Valtonen, 2003 ; Sinisalo et al. 2004). C. semerme and C. strumosum were reported in 15 and 10 fish species, respectively, in Lake Ladoga by Barysheva \& Bauer (1957). However, based on the results of one dissected seal from Lake Ladoga caught in 1992 in which hundreds of $C$. semerme and 111 C. magdaleni were found, but not a single C. strumosum (Sinisalo T. unpublished data), it is likely that only C. semerme and C. magdaleni occur in Lake Ladoga, too. C. magdaleni was not even described in the 1930s and 1940s at the time Barysheva and Bauer collected their data. Water from Lake Saimaa flows via Lake Ladoga to the Gulf of Finland off the Baltic Sea.

The freshwater affinities of $C$. magdaleni and $C$. semerme are serving them well: they have not only withstood changes in host abundance in the Bothnian Bay but also the decreasing salinities in the area. In contrast, C. strumosum has not been reported from freshwater habitats except the questionable findings in Lake Ladoga (see above). From 1988, this species showed the lowest values of prevalence and abundance of the 3 parasite species. Although its mean abundance still shows no statistical link with that of the seal host (perhaps only because its numbers cannot be analysed separately from those of C. magdaleni in 1977-1982), it consistently shows a low proportion of mature females. The status of the C. strumosum population in the Bothnian Bay appears more at risk than that of the other 2 species. This is probably not because of varying seal numbers but more likely because of the increasing shift of the bay toward a freshwater environment, a change that has caused the disappearance of $C$. strumosum's main paratenic host, the bull rout (O. Timola, unpublished observations).

Montreuil (1958) described C. magdaleni from the grey seal taken from the Gulf of St. Lawrence in eastern Canada. C. magdaleni was not reported again until Delyamure et al. (1980) found it in 3 ringed seals from the Gulf of Finland, Baltic Sea. The subsequent reports of C. magdaleni were those of C. magdaleni adults in grey seals of SW Archipelago sea between the Gulf of Bothnia and the Baltic proper (Nickol et al. 2002) and cystacanths in fishes of the Bothnian Bay (Sinisalo \& Valtonen, 2003) and from the isolated land-locked ringed seal population 
of Lake Saimaa in SE Finland (Sinisalo et al. 2003, 2004). The present finding of $C$. magdaleni in ringed seals of the Bothnian Bay confirms the status of ringed seals as a genuine definitive host of C. magdaleni in the Baltic Sea, not only in the Lake Saimaa population where $C$. magdaleni is the only acanthocephalan species ever found (Sinisalo et al. 2003, 2004).

Our results suggest that it is difficult to infer any changes in parasite population dynamics from changes in host abundance, at least in parasite species with complex (multi-host) life-cycles. Although the data are patchy and must be interpreted with some caution, it appears that in the Bothnian Bay, environmental (salinity) changes and fluctuations in the abundance of one or more hosts in the life-cycle had no measurable impact on the abundance of the acanthocephalan species. Of course, since total adult parasite population size equals the product of mean abundance and seal numbers, the total size of the parasite population may have fluctuated with seal numbers. Given the small sample sizes in some years, extrapolation of the total parasite population size is likely to be inaccurate; still, when we repeated our analysis using estimates of total parasite population size, we again found no temporal trends (unpublished observations). The grey seal may play some role in maintaining the Corynosoma populations in the Bothnian Bay but is of minor importance because changes in the population size of grey seals are paralleled by those of the ringed seals, and the grey seal numbers are only a small fraction of those of the ringed seals. Therefore our results indicate that, on a per-host-capita basis, the transmission dynamics of the parasites has shown remarkable stability.

The authors acknowledge the Research Council for Bioscience and Environment within the Academy of Finland for the opportunity of E. T. Valtonen and R. Poulin to work together in New Zealand in spring 2003.

\section{REFERENCES}

ANDERSON, R. M. \& MAY, R. M. (1978). Regulation and stability of host-parasite population interactions. I. Regulatory processes. Fournal of Animal Ecology 47, 219-247.

ANDERSON, R. M. \& MAY, R. M. (1979). Population biology of infectious diseases: part I. Nature, London 280, 361-367.

BARYSHEVA, A. F. \& BAUER, O. N. (1957). Fish parasites of Lake Ladoga. In Parasites and Diseases of Fish (ed. Petrushevskii, G. K.), pp. 171-223. Bulletin of the All-Union Scientific Research Institute Fresh-water Fisheries. XLII, The Israel Program for Scientific Translations, Jerusalem.

ChubB, J. C., VAltonen, E. T., McGeorge, J. \& Helle, E. (1995). Characterization of the external features of Schistocephalus solidus (Müller, 1776) from different geographic regions and assesment of the status of the Baltic ringed seal (Phoca hispida botnica) (Gmelin,
$1785)$ as definitive host. Systematic Parasitology 32, 113-123.

Delyamure, S. L., POPOV, v. N. \& TRASHChEnKOV, A. N. (1980). A study of the helminth fauna of seals in the Baltic Sea and Lake Ladoga. Doklady Vysshei Shkoly, Biologicheskie Nauki 7, 43-45.

DONner, J. (1995). The Quaternary History of Scandinavia. Cambridge University Press, Cambridge, UK.

HÄRKÖNEN, T., STENMAN, O., JUSSI, M., JUSSI, I., SAGITOV, R. \& Verevkin, M. (1998). Population size and distribution of the Baltic ringed seal (Phoca hispida botnica). NAMMCO Scientific Publications I, 167-180.

HÅRDING, K. C. \& HÄRKÖNEN, T. (1999). Development in the Baltic grey seal (Halichoerus grypus) and ringed seal (Phoca hispida) populations during the 20th century. Ambio 28, 619-627.

Helle, E. (1980). Aerial census of ringed seals Pusa hispida basking on the ice of the Bothnian Bay, Baltic. Holarctic Ecology 3, 183-189.

HELlE, E. (1986). The decrease in the ringed seal population of the Gulf of Bothnia in 1975-84. Finnish Game Research 44, 28-32.

Helle, E. \& VALTONEN, E. T. (1980). On the occurrence of Corynosoma spp (Acanthocephala) in ringed seals (Pusa hispida) in the Bothnian Bay, Finland. Canadian Fournal of Zoology 58, 298-303.

Helle, E. \& VAltonen, E. T. (1981). Comparison between spring and autumn infection by Corynosoma (Acanthocephala) in the ringed seal Pusa hispida in the Bothnian Bay of the Baltic Sea. Parasitology 82, 287-296.

KOKKo, H., Helle, E., LINDSTRÖM, J., RANTA, E., SIPILÄ, T. \& COURCHAMP, F. (1999). Backcasting population sizes of ringed and grey seals in the Baltic and Lake Saimaa during the 20th century. Annales Zoologi Fennici 36, $65-73$.

LEONARDSson, K., ANDERSIN, A.-B., MÄKINEN, A. \& RÖnnberg, O. (1996). Benthic Biology. In Third Periodic Assessment of the State of the Marine Environment of the Baltic Sea, 1989-1993; Background Document. Baltic Sea Environment Proceedings No. 64B, 42-46.

MAY, R. M. \& ANDERSON, R. M. (1978). Regulation and stability of host-parasite population interactions. II. Destabilizing processes. Fournal of Animal Ecology 47, 249-267.

MAY, R. M. \& ANDERson, R. M. (1979). Population biology of infectious diseases: part II. Nature, London 280, $455-461$.

MONTREull, P. L. (1958). Corynosoma magdaleni sp. nov. (Acanthocephala), a parasite of the grey seal in eastern Canada. Canadian Fournal of Zoology 36, 205-215.

NiCKOL, B. B., HELle, E. \& VAlTONEN, E. T. (2002).

Corynosoma magdaleni in gray seals from the Gulf of Bothnia, with amended descriptions of C. strumosum and C. magdaleni. Fournal of Parasitology 88, 1222-1229.

Petrochenko, v. I. (1956). Acanthocephala of Domestic and Wild Animals Vol. I : Izdatel'stvo Akademii Nauk SSSR, Moscow.

Sinisalo, T. \& VAltonen, E. T. (2003). Corynosoma acanthocephalans in their paratenic fish hosts in the Northern Baltic Sea. Parasite 10, 227-233.

Sinisalo, T., KUNNASRANTA, M. \& VALTONEN, E. T. (2003). Intestinal helminths of a landlocked ringed seal (Phoca hispida saimensis) population in the Eastern Finland. Parasitology Research 91, 40-45. 
SINISAlO, T., POULIN, R., HÖGMANDER, H., JUUTI, T. \& VALTONEn, E. T. (2004). The impact of sexual selection of Corynosoma magdaleni (Acanthocephala) infrapopulations in Saimaa ringed seals (Phoca hispida saimensis). Parasitology 128, 179-185.

VALtonen, E. T. (1983a). On the ecology of Echinorhynchus salmonis and two Corynosoma species (Acanthocephala) in the fish and seals of the northern Gulf of Bothnia. $\mathrm{PhD}$ thesis. Acta Universitatis Ouluensis, Series A Scientiae Rerum Naturalium No. 156, Biologica 22, $1-49$.

VAltonen, E. T. (1983b). Relationships between Corynosoma semerme and C. strumosum (Acanthocephala) and their paratenic fish hosts in the Bothnian Bay, Baltic Sea. Acta Universitatis Ouluensis, Series A Scientiae Rerum Naturalium No.155, Biologica 21, 1-32.

VAltonen, E. T. \& Helle, E. (1988). Host-parasite relationships between two seal populations and two species of Corynosoma (Acanthocephala) in Finland. Fournal of Zoology, London 214, 361-371.

WiKner, J. (1996). Gulf of Bothnia (Bothnian Bay, Bothnian Sea, Åland Sea, Archipelago Sea). In Third Periodic Assessment of the State of the Marine Environment of the Baltic Sea, 1989-93; Background document. Baltic Sea Environment Proceedings 64B, $28-46$. 